\title{
USE OF INFLOW AREAS IN TWO COLORADO RIVER BASIN RESERVOIRS BY THE ENDANGERED RAZORBACK SUCKER (XYRAUCHEN TEXANUS)
}

\author{
Brandon Albrecht ${ }^{1,8}$, Harrison E. Mohn ${ }^{1}$, Ron Kegerries ${ }^{1}$, Mark C. McKinstry ${ }^{2}$, Ron Rogers ${ }^{1}$, \\ Travis Francis ${ }^{3}$, Brian Hines ${ }^{4}$, James Stolberg ${ }^{5}$, Dale Ryden ${ }^{3}$, Darek Elverud ${ }^{3}$, \\ Benjamin Schleicher ${ }^{3}$, Katherine Creighton ${ }^{4}$, Brian Healy ${ }^{6}$, and Brandon Senger ${ }^{7}$
}

\begin{abstract}
During the last century, populations of the endangered Razorback Sucker (Xyrauchen texamus) have declined in the Colorado River Basin. Dramatic changes in habitat resulting from altered flow regimes and the presence of nonnative fishes were likely major factors contributing to this decline. Since 1996, studies in Lake Mead have resulted in the discovery of 4 areas where wild Razorback Suckers were spawning; all of these locations have tributary or wastewater inflows. Since the Lake Mead Razorback Sucker population has persisted near these prominent inflow areas, we hypothesize that complex inflow areas with vegetative cover and turbidity provide important habitat for the species. In 2011, Razorback Sucker investigations at the Lake Powell-Colorado River inflow and the Lake Powell-San Juan River inflow were initiated and, similar to Lake Mead, we found large numbers of Razorback Suckers using both of these inflow areas. Multiple age classes of Razorback Suckers were found in Lake Powell, along with spawning activity and Razorback Sucker larvae, but wild recruitment was more difficult to document due to the large numbers of fish stocked upstream into the Colorado and San Juan Rivers that may have moved into the reservoir. Since Razorback Suckers are present at the prominent inflow areas of Lakes Mead and Powell, we compared reservoir-specific research and monitoring data to highlight the potential for Razorback Sucker recruitment and to promote the importance of these areas for species conservation and recovery. Our research suggests that inflow areas in Lakes Mead and Powell may provide the criteria necessary for Razorback Suckers to reproduce, grow, and persist.
\end{abstract}

RESUMEN.-Durante el siglo pasado, las poblaciones de matalote jorobado (Xyrauchen texanus) en peligro han disminuido en la cuenca del Rio Colorado. La alteración en los regímenes del flujo y la presencia de peces exóticos han resultado en cambios dramáticos en el hábitat contribuyendo al declive de esta especie. Desde 1996, estudios en el Lago Mead han resultado en el descubrimiento de 4 áreas de desove del matalote jorobado; estas zonas tienen tributarios o flujo de aguas residuales. Ya que hay poblaciones de matalotes jorobados que persisten cerca de estas prominentes afluencias, tenemos la hipótesis de que en áreas de afluencia complejas con cobertura vegetal y turbiedad proveen hábitat para la especie. En 2011, se iniciaron investigaciones sobre el matalote jorobado en el afluente del Lago Powell-Colorado y del Lago Powell-San Juan y, similar al Lago Mead, encontramos grandes números de matalotes jorobados en ambos afluentes. Se encontraron múltiples clases de edad de matalotes en el Lago Powell, junto con actividad de desove y larvas de matalotes, sin embargo el reclutamiento silvestre resultó más difícil de documentar debido a los grandes números de peces acumulados río arriba en los Ríos Colorado y San Juan que tal vez fueron trasladados en la reserva. Debido a que los matalotes jorobados están presentes en áreas de afluencia prominentes de los Lagos Mead y Powell, comparamos investigaciones específicas de la reserve y monitoreamos los datos para enaltecer el potencial de los matalotes para reclutar y promover la importancia de estas áreas para la conservación y la recuperación de especies. Nuestra investigación sugiere que las áreas de afluencia en los Lagos Mead y Powell pueden proveer los criterios necesarios para la reproducción, el crecimiento y la persistencia de los matalotes jorobados.

Desert fish species have steadily declined in richness and abundance during the last century, primarily due to anthropogenic causes (Minckley and Deacon 1991). Native fishes of the Colorado River are affected by mainstem dam construction, which results in reservoir habitats and cool tailwaters replacing the natural warm riverine environment (Holden and Stalnaker 1975, Joseph et al. 1977, Wick et al. 1982, Minckley et al. 1991, 2003, Mueller 2006, Bestgen et al. 2011). Furthermore, invasion of the Colorado River basin by nonnative predators and competitors is a primary threat to recruitment and recovery of native species (Minckley et al. 1991, Marsh et al. 2003, 2015). The Razorback Sucker

\footnotetext{
1BIO-WEST, Inc, 1063 West 1400 North, Logan, UT 84321.

${ }^{2}$ U.S. Bureau of Reclamation, Upper Colorado Region, 125 South State Street, Salt Lake City, UT 84138.

${ }^{3}$ U.S. Fish and Wildlife Service, Grand Junction Fish and Wildlife Conservation Office, 445 West Gunnison Ave., Suite 140, Grand Junction, CO 81501.

${ }^{4}$ Utah Division of Wildlife Resources, Moab Field Station, 1165 S. Hwy. 191, Suite \#4, Moab, UT 84532.

${ }^{5}$ U.S. Bureau of Reclamation, Lower Colorado River Multi-Species Conservation Program, Box 61470, LC-8000, Boulder City, NV 89006.

${ }^{6}$ U.S. National Park Service, Grand Canyon National Park, 1824 South Thompson Street, Flagstaff, AZ 86001.

${ }^{7}$ Nevada Department of Wildlife, 4747 Vegas Drive, Las Vegas, NV 89108.

${ }^{8}$ Corresponding author. E-mail: balbrecht@bio-west.com
} 
(Xyrauchen texanus [Abbott]) is one of 4 endemic "big-river" fish species of the Colorado River Basin currently listed by the federal government as endangered (USFWS 1991). The other 3 listed species are the Colorado Pikeminnow (Ptychocheilus lucius), Bonytail (Gila elegans), and Humpback Chub (Gila cypha). Fossil records suggest that these endemic native fishes of the Colorado River have existed for 3-5 million years (Miller 1958, Minckley et al. 1986). During the Pleistocene Epoch, the Colorado River Basin was volcanically active, and lava-flow dams created large natural lakes (Dalrymple and Hamblin 1998). In response, the Razorback Sucker likely had to adapt to both riverine and lacustrine habitats. The Razorback Sucker was historically widespread and common throughout the larger rivers of the Colorado River basin (Minckley et al. 1991); however, current Razorback Sucker distribution and abundance are greatly reduced from historic levels (Minckley and Marsh 2009, Albrecht et al. 2010, Bestgen et al. 2011, Marsh et al. 2015).

Because sustained recruitment was lacking, researchers predicted that populations of longlived Razorback Suckers would collapse 40-50 years following reservoir creation (Minckley 1983, Marsh et al. 2015). Razorback Suckers were numerous in Lake Mead, but they noticeably decreased following the 1963 closure of the upstream Glen Canyon Dam (Minckley et al. 1991). The species was thought to have disappeared by the 1980s (Minckley 1973, McCall 1980, Minckley et al. 1991, Albrecht et al. 2010). Holden et al. (2000a, 2000b) systematically searched the shoreline of Lake Mead for 2 spawning seasons and found all Razorback Sucker larvae near inflow areas, except for 2 individuals. Subsequently, more than a decade of trammel netting, telemetry, and larval sampling throughout Lake Mead has resulted in the discovery of 4 areas routinely used by Razorback Suckers (Albrecht et al. 2008, 2010, Kegerries et al. 2016). Three of these areas are located near permanent inflows (Las Vegas Bay, the Virgin River/Muddy River inflow area, and the Colorado River inflow area). The other area is near a large, intermittent wash inflow (Echo Bay; Albrecht et al. 2010, Mohn et al. 2016). All of these areas deliver sediment and turbidity (Fig. 1).

Due to loss of the Razorback Sucker throughout the Colorado River basin, augmentation is a long-standing key component of the Upper Colorado River Endangered Fish Recovery Program (established in 1988) and the San Juan River Basin Recovery Implementation Program (established in 1992). These 2 programs aim to recover the 4 bigriver fish species and provide the "Reasonable and Prudent Alternative" that allows for past and future water development projects (currently numbering more than 3500) in the Upper Colorado River basin (i.e., upstream of Glen Canyon Dam; USFWS 2009). To meet program goals, agencies and researchers have stocked more than 140,000 Razorback Suckers into the San Juan River subbasin and approximately 370,000 additional Razorback Suckers throughout Upper Colorado River subbasins upstream of Lake Powell (STReaMS 2017). In both river subbasins, fish have unimpeded downstream access to Lake Powell. Thus, the Upper Colorado River and Lake Mead populations of Razorback Sucker are inherently different; the Lake Powell population consists largely of stocked fish (Francis et al. 2013), while Lake Mead has no formal stocking program (Albrecht et al. 2010). We acknowledge that some stocking of Razorback Suckers (350 individuals by multiple agencies) has occurred within Lake Mead from 1995 to 2016; however, all fish were marked with passive integrated transponders (PIT) tags in order to determine their origin. There are 2 sites near Lake Mead that contain Razorback Suckers, and each has a potential connection to Lake Mead. One is NDOW's Lake Mead Fish Hatchery, where Razorback Suckers are typically PIT tagged upon reaching approximately $250 \mathrm{~mm}$ total length (TL). The other source includes 2 off-channel ponds at the Overton Wildlife Management Area, where all Razorback Suckers are PIT tagged prior to being stocked. To our knowledge, there have been no unintentional releases or escapes of unmarked fish from either facility.

Although Razorback Sucker habitat has been altered and reduced, diverse habitat still exists near inflow areas that provide conditions that can support large numbers of species and life stages, presumptively through habitat diversity, niche availability, and primary productivity resulting from combinations of lotic and lentic habitats (Karp and Mueller 2002, Kaemingk et al. 2007, Hines 2011). One important characteristic of these complex habitats is elevated turbidity, which is often caused by suspended sediments from 


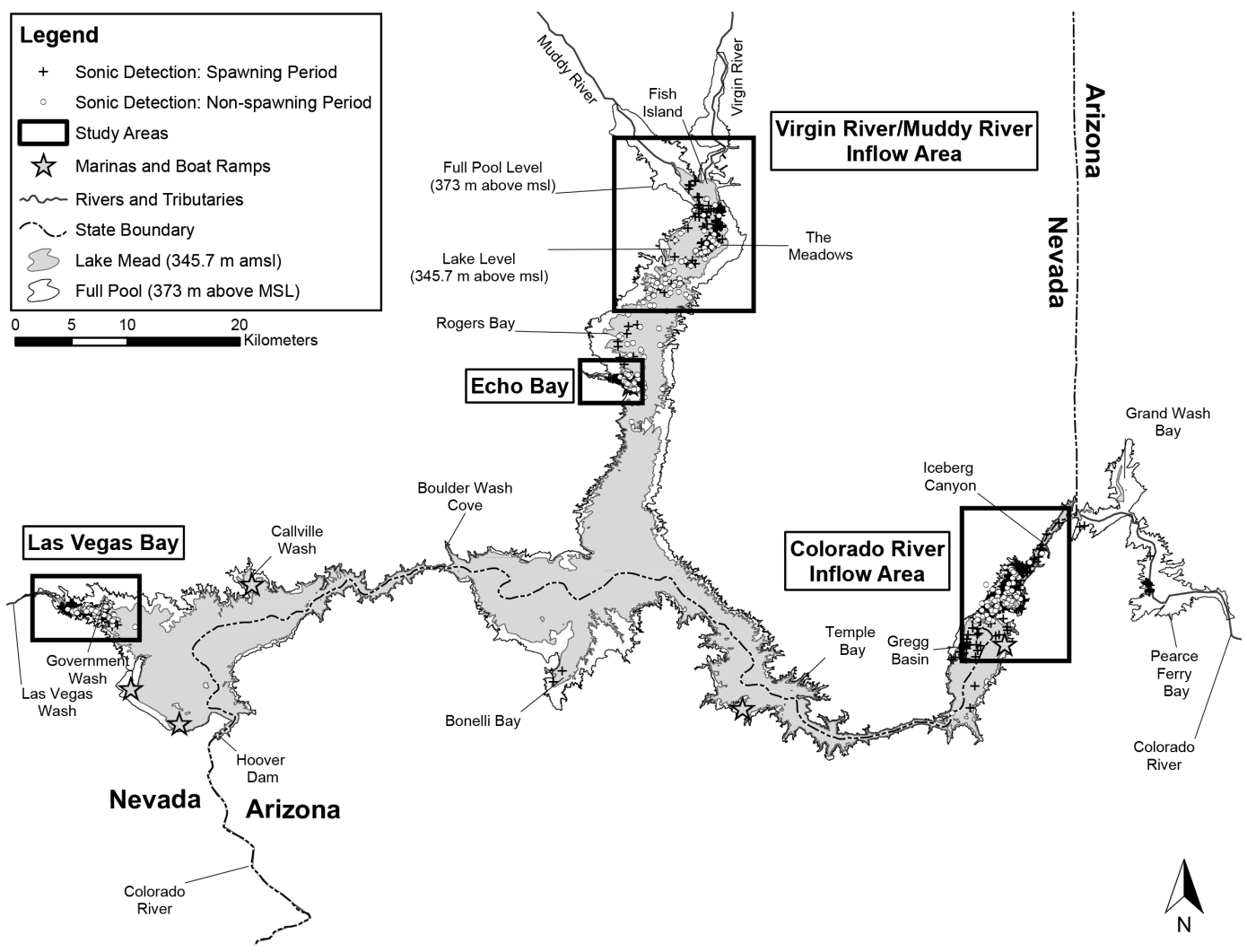

Fig. 1. Study areas and geographic landmarks within Lake Mead. Also shown are telemetry contacts during spawning months (January-May, represented by + ) and nonspawning months (June-December, represented by $O$ ) during the years 2010-2016.

riverine sediment transport and wave action (e.g., Albrecht et al. 2010). This turbidity likely reduces nonnative fish predation on larval, juvenile, and adult fish (Johnson and Hines 1999, Albrecht et al. 2010, Ward et al. 2016).

Razorback Sucker sampling and telemetry data from Lakes Mead and Powell are presented below in an effort to better document use of reservoir inflow areas by Razorback Sucker. Our goal is to highlight Razorback Sucker recruitment (larvae surviving to reproductive age) potential within these 2 Colorado River basin inflow areas, which could help guide conservation and recovery efforts for the species.

\section{Methods}

\section{Study Areas}

The primary study areas in Lake Mead included Las Vegas Bay, the Virgin River/ Muddy River inflow area, Echo Bay, and the
Colorado River inflow area (Fig. 1). Razorback Suckers in Lake Mead have been monitored for the last 20 years, but studies at the Colorado River inflow area began in 2010 . We limit our data to the last 7 years of study (2010-2016), when all sampling areas were sampled concurrently. The Lake Mead study areas were sampled annually via telemetry, nighttime larval sampling, and trammel netting (detailed below) throughout the spawning season (December-May), and additional telemetry was conducted during the nonspawning season (June-November). All sampling in Lake Powell occurred during the spawning season (March-June) within the San Juan River inflow area (PSJ) during 2011-2012 and within the Colorado River inflow area (PCR) during 2014-2015 (Fig. 2). We analyzed most Lake Mead netting and telemetry data together for ease of comparison. Limited movement occurs between Lake Powell sampling locations (Durst and Francis 2016), but 


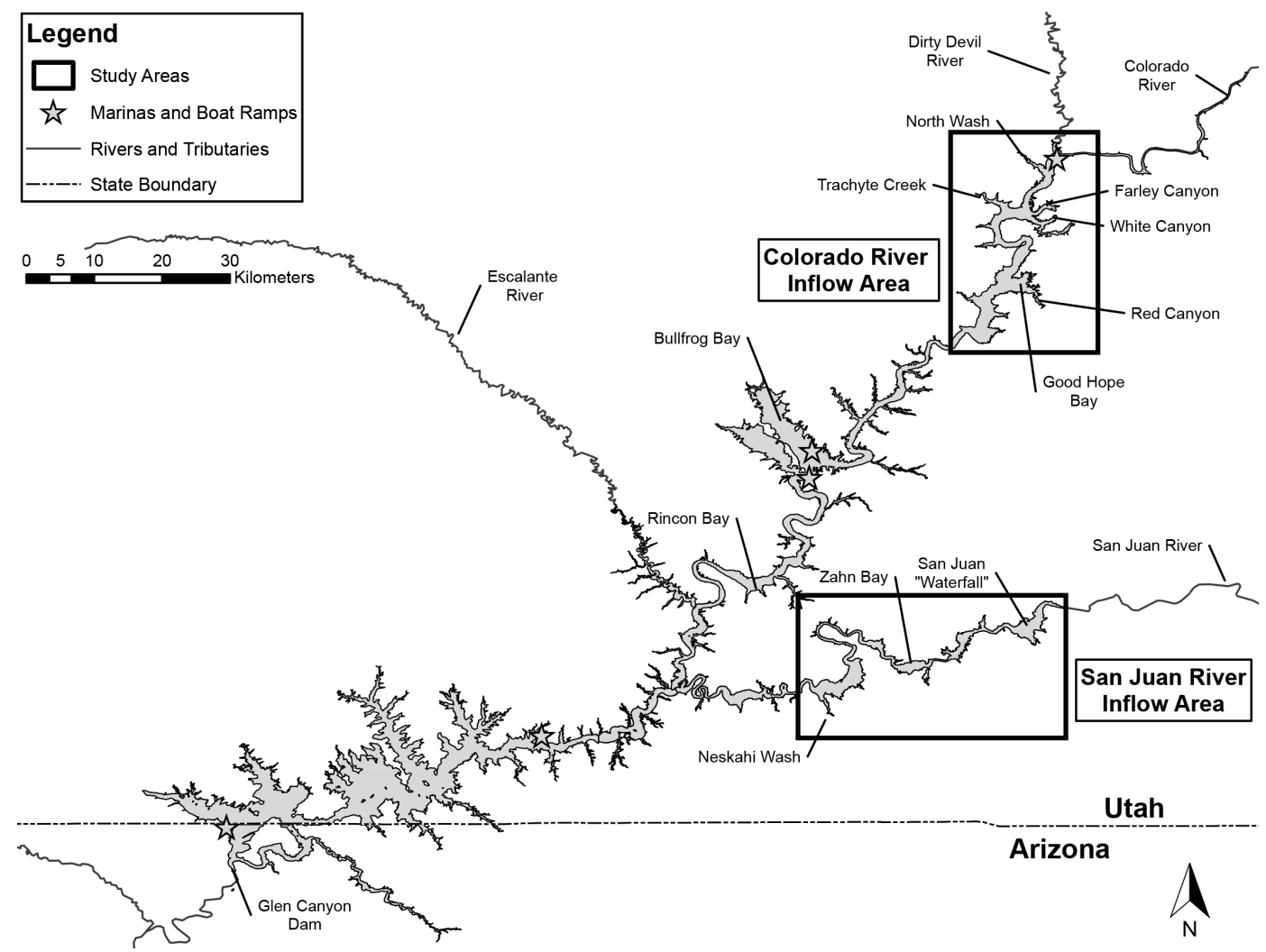

Fig. 2. Study areas and geographic landmarks within Lake Powell, including the San Juan River inflow area (PSJ) and the Colorado River inflow area (PCR).

we chose to analyze sites individually until additional years of data can be collected from Lake Powell sampling to better inform connections between sites.

We define inflow areas as the combination of riverine and lacustrine habitats that include complex habitats found both above and below the actual river and reservoir interface at the time of sampling. Our definition also includes the flowing portion and wetted floodplain habitat within the river, as well as reservoir habitat that is influenced by debris and turbidity from the river. These inflow habitats change over time, depending on river discharge and subsequent fluctuations in reservoir elevation.

\section{Telemetry}

TAGgInG.-Surgically implanted Sonotronics model CT-05-48-I (48-month) tags were most commonly used in Razorback Suckers during these studies. The 48-month tags had a water weight of $12 \mathrm{~g}$ and measured $79.0 \mathrm{~mm}$ long by $15.6 \mathrm{~mm}$ in diameter. Tag frequencies ranged from 69 to $83 \mathrm{kHz}$ and, because each tag had a unique code, individual fish were readily distinguished. Additionally, some Razorback Suckers were implanted with Sonotronics model ART-01 tags, which had a water weight of $12 \mathrm{~g}$, measured $105.0 \mathrm{~mm}$ long by $18.0 \mathrm{~mm}$ in diameter, and had a radio frequency of $148.83 \mathrm{mHz}$ and a sonic acoustic (sonic) frequency of $75 \mathrm{kHz}$. Hereafter, the terms telemetry or tag will refer to telemetry using either sonic or dual-functioning (sonic and radio) tags.

Surgical protocols used for these studies were modified from Valdez and Nilson (1982) and Kaeding et al. (1990). A transmitter-to-fish air weight of $2 \%$ was used as a guideline to ensure that the tags were not too large for the fish (Bidgood 1980, Marty and Summerfelt 1990). Surgery was performed on shore or boat for wild fish captured during sampling 
efforts and in the hatchery for raised fish (hatchery fish were used as "Judas" fish in Lakes Mead and Powell). Prior to surgery, each fish was placed in a live well containing fresh reservoir or hatchery water. All surgical instruments were cold sterilized with iodine and 95\% ethanol and allowed to air dry on a disposable sterile cloth. Razorback Suckers were anesthetized with a clove oil/ethanol mixture following Bunt et al. (1999). After anesthesia was induced, total length (TL), fork length (FL), standard length (SL), and weight of each fish were recorded. Fish were then placed dorsal-side down on a padded surgical cradle for support during surgery. Head and gills were submerged in reservoir or hatchery water with a maintenance concentration of clove oil/ethanol anesthetic following Bunt et al. (1999). Following fish introduction to the maintenance anesthetic, the surgeon made an approximately $2-\mathrm{cm}$ incision on the left side posterior to the pelvic girdle. A PIT tag was placed into the incision of previously unmarked fish, and the transmitter was pushed between the pelvic girdle and urogenital pore. The incision was closed with 2-4 sutures using 3-0 Maxon absorbable poliglecaprone 25 monofilament suture with an attached PS-1 reverse-cutting curved needle. Surgical times typically ranged from 2 to 5 min per fish.

After surgery, fish were allowed to recover and were closely monitored until equilibrium was maintained. Once fully recovered, tagged fish were either released at their original point of capture or held in the hatchery for transport and release. Upon release, all fish were reexamined for signs of stress. Tracking ensued immediately after release.

Tracking.-In Lake Mead, tagged fish were tracked monthly or more often, depending on project goals. Fish searches were conducted largely along shorelines with listening points approximately $0.8 \mathrm{~km}$ apart, but searches varied based on shoreline configuration and other factors that could impact signal reception. Telemetry signals are lineof-sight, and any obstruction can reduce or block reception.

Active tracking consisted of listening underwater for coded sonic tags using a Sonotronics USR-08 ultrasonic receiver and a DH4 directional or TH-2 omnidirectional hydrophone for acoustic signals. The direc- tional hydrophone was lowered into the water and rotated $360^{\circ}$ to detect the presence of sonic-tagged fish. Once a signal was detected, the position of the sonic-tagged fish was pinpointed by adjusting the gain (sensitivity) on the receiver and moving in the fish's direction until the signal was heard in all directions with the same intensity. Active tracking was supplemented by using a Lotek SRX 400a receiver and a Telonics RA-2AK VHF antenna to track Razorback Suckers implanted with dual radio/sonic tags. When a fish was detected, the directional hydrophone was employed to pinpoint the location of the detected fish and determine the fish code.

Telemetry surveys were conducted throughout Lake Mead, and sonic/radio-tag codes, GPS locations, and habitat characteristics (i.e., depth, weather, cover, and in some cases vegetation and substrate) were recorded in all cases. We did not conduct active telemetry efforts in Lake Powell because the study was new and we had not yet employed active tracking.

To assess inflow use, Lake Mead active telemetry contacts were segregated by spawning months (December-May) and nonspawning months (June-November). ArcGIS 10.5 was used to plot all sonic/radio fish contact locations in Lake Mead from 2010 to 2016 during the spawning and nonspawning months to demonstrate any habitat use patterns. Additionally, during 2010-2016 the distance from the river interface, as measured at each inflow from the highest water level recorded, was calculated for each contact as a means to quantify Razorback Sucker proximity to and use of inflow areas.

\section{Larval Fish Sampling}

Larval sampling in Lake Mead was conducted following Burke (1995) by connecting two 12-V fishing lights (Brinkmann Starfire II halogen underwater fishing lights) to a battery, placing the lights over each side of the boat, and submerging them in 10-25 cm of water. Two field personnel (one for each light) equipped with long-handled aquarium dip nets observed the area around each light for 15 min. Sucker larvae that swam into the lighted area were dipnetted out of the water, enumerated, and placed into a holding bucket. When appropriate, field personnel released the larvae at the point of capture when sampling was completed and repeated the procedure 
at 4-12 sites on each night when sampling was attempted. Due primarily to water temperatures, other fish species (e.g., Gizzard Shad [Dorosoma cepedianum], Common Carp [Cyprinus carpio]) within Lake Mead typically spawn after Razorback Suckers, and their larvae are rarely present during Razorback Sucker larval fish surveys (Holden et al. 1997, Snyder and Muth 2004, Snyder et al. 2016). Furthermore, swimming Gizzard Shad and Common Carp are easily distinguished from sucker larvae based on their different body shapes and swimming movements; thus, those fish were not captured. Periodic collection of larvae for hatchery rearing helped to positively confirm field identification of Razorback Sucker larvae in Lake Mead (E. Laux, Nevada Department of Wildlife, personal communication). In areas of Lake Mead where Flannelmouth Suckers (Catostomus latipinnis), Desert Suckers (Catostomus clarki), Bluehead Suckers (Catostomus discobolus), and/or hybrid suckers were found (e.g., the Colorado River inflow area), subsamples were preserved in $10 \%$ formalin for microscopic verification using a key to catostomid fish larvae developed by Snyder and Muth (2004). Initial specimens were also analyzed and verified by Darrel Snyder (Larval Fish Laboratory, Colorado State University, Fort Collins, CO). Specimens from the Colorado River inflow area were preserved by field crews and verified by specialists at American Southwest Ichthyological Researchers, LLC, to help ensure the validity of field identifications. A portion of Razorback Sucker larvae from Lake Mead were provided for genetic analysis as part of ongoing longterm monitoring efforts, and results of the genetic analysis further supported the species determinations made by field crews (Dowling et al. 2012).

Larval light traps became a primary method used in Lake Powell to collect catostomid larvae because of concerns for field crew safety (e.g., dangerous sampling locations for nighttime navigation). Larval light traps were deployed overnight by anchoring the trap to nearshore vegetation in suspected spawning areas or in habitats with little to no current velocity (Killgore 1991). White light sticks (Cyalume ${ }^{\circledR} 15.24 \mathrm{~cm}, 12 \mathrm{~h}$ ) were inserted into the trap, and the trap was allowed to float freely (Mueller et al. 1993). Light traps were collected the next morning and checked for larval fish. All larval fish from Lake Powell were retained so they could be identified in the laboratory by specialists at American Southwest Ichthyological Researchers, LLC.

We limited the results to total counts of Razorback Sucker larvae found at each site, within each reservoir, and across years sampled. We do not present catch per unit effort due to differences in sampling methodologies and efforts between reservoirs. The ultimate goal was to determine presence or absence of larvae to confirm successful Razorback Sucker reproduction upstream of or within each inflow area complex.

\section{Juvenile and Adult Fish Sampling}

The primary gear used to sample juvenile and adult fish were trammel nets, with the most commonly used sizes being either $91.4 \mathrm{~m}$ long by $1.8 \mathrm{~m}$ deep or $45.7 \mathrm{~m}$ long by $1.2 \mathrm{~m}$ deep with internal panels of 2.54-cm mesh and external panels of $30.48-\mathrm{cm}$ mesh. We selected netting locations according to the locations of sonic-tagged individuals, high concentrations of Razorback Sucker larvae, and knowledge of Razorback Sucker use of the area from the previous sampling periods. Nets were generally deployed in the late afternoon and removed in the early morning for overnight sets during January-May in Lake Mead and March-June in Lake Powell. Daytime sets were generally deployed in late morning and removed in early evening.

We used electrofishing opportunistically in Lake Powell to capture additional Razorback Suckers and help locate other potential spawning sites. Electrofishing was conducted using a 16-foot aluminum jon boat outfitted with a Smith-Root GPP electrofisher, two 22.9-cm stainless steel anodic hemispheres, a cathodic hull, and $122.0-\mathrm{cm}$ cathodic stainless steel dropper cables. The electrofishing crew typically consisted of 2 netters and 1 boat operator. We combined electrofishing captures with trammel netting captures to compare Razorback Sucker age, growth, and condition information between Lakes Mead and Powell. We do not provide an electrofishing catch per unit effort nor do we combine it with trammel netting catch per unit effort because electrofishing was only conducted in Lake Powell.

Following capture by either method, Razorback Suckers were held in aerated live wells and then weighed, measured to the nearest 
millimeter (TL, FL, SL), and marked with a PIT tag if the individual was untagged. Captured Razorback Suckers also were assessed for reproductive status (i.e., presence of tubercles, prespawn, ripe, running, spent) and general health (blindness, sores or lesions, etc.). Razorback Suckers captured for the first time were fin-clipped for age determination using procedures outlined in Albrecht et al. (2010). We calculated catch rates of Razorback Suckers captured via trammel netting as the number of fish captured per net-hour fished.

We compared total body length and relative weight between fish from Lakes Mead and Powell. Growth rates were calculated as $\mathrm{mm} /$ year grown between first and second capture of an individual. Relative weight $\left(W_{r}\right)$, a measure of fish body condition, was determined using equations specific to Razorback Sucker, as published in Didenko et al. (2004), and compared among study areas. Differences for all population demographic measures were determined using a one-way ANOVA with significance at $P \leq 0.05$. We made pairwise comparisons between reservoirs and trapping locations using the Tukey-Kramer honest significant difference (HSD) test, as appropriate and applicable. Although a Shapiro-Wilk test indicated nonnormality in residuals (due to our sample sizes), visual inspection of the randomly dispersed residuals of each data set indicated that the normality assumption would not be violated. Additionally, ANOVA is robust to violations of the normality assumption (Lumley et al. 2002, Pallant 2007), and we therefore used an ANOVA to compare means among treatments despite the results of the Shapiro-Wilk test. We graphed results using a kernel density estimation in the Excel add-on "NumXL." We used a Gaussian kernel type and the optimal bandwidth selection tool. To determine whether capture location was related to growth or size of the fish, we used von Bertalanffy growth curves by means of the Fabens (1965) method as detailed in Guy and Brown (2007).

\section{Age Determination}

To better understand recruitment as it relates to environmental factors, we used a nonlethal technique to collect fin ray sections to age Razorback Suckers captured during this study. Lake Mead Razorback Suckers captured from 2010 to 2016 were aged following methods modified from McCarthy and
Minckley (1987) and first described in Holden et al. (2000a) where ages were verified by comparing otoliths of known-age hatchery fish. The same method was also described in Albrecht et al. (2010) for analyzing year-class strength and supporting continued recruitment in Lake Mead. This manuscript updates recruitment years of Razorback Suckers in Lake Mead from 2010 to 2016 and documents similar age information obtained from Razorback Suckers captured at the PCR from 2014 to 2015 and the PSJ from 2011 to 2012 .

\section{RESULTS}

\section{Telemetry}

In Lake Mead, sonic/radio-tagged fish were contacted 1878 times during spawning and nonspawning months. Approximately $40 \%$ of the contacts occurred within $5 \mathrm{~km}$ of the riverlake interface, as calculated from the highest water level recorded during 2010-2016, and $80 \%$ of the contacts occurred within $10 \mathrm{~km}$ of the interface (Fig. 1). Sixty-one percent of sonic/radio-tagged fish within $10 \mathrm{~km}$ of the river-lake interface were detected during December through May (spawning months).

\section{Larval Fish Sampling}

Larval Razorback Suckers were captured in both Lakes Mead and Powell, which documented the species' presence and successful reproduction. The number of larval Razorback Suckers captured at individual sites in both reservoirs ranged from 0 to 3818 during the study period. The mean catch for Lake Mead sites during 2010 to 2016 was 328 (SE 135) larval Razorback Suckers per year (Table 1). Within Lake Powell, catch varied between the 2 study areas. One larval Razorback Sucker was captured in the PSJ during 2011-2012, while larval sampling at the PCR during 2014-2015 resulted in a mean of 1087 (SE 206) larval Razorback Suckers captured per year.

\section{Juvenile and Adult Fish Sampling}

The fish communities in Lakes Mead and Powell, as assessed through trammel netting efforts, consisted of 21 species (Table 2), including 5 native species and 1 hybrid sucker combination (Razorback Sucker, Flannelmouth Sucker, Bluehead Sucker, Colorado Pikeminnow, Bonytail, and Razorback Sucker $\times$ Flannelmouth Sucker hybrids). At each location, 
TABLE 1. Razorback Sucker larvae captured from 2010 to 2016 at each sampling site in Lake Mead and Lake Powell. NS indicates that the site was not sampled. EB = Echo Bay, LB = Las Vegas Bay, VR/MR = Virgin River/Muddy River inflow area, CRI $=$ Colorado River inflow area, PCR $=$ Lake Powell-Colorado River inflow area, PSJ $=$ Lake Powell-San Juan inflow area.

\begin{tabular}{lcrrrrrrrr}
\hline & & \multicolumn{7}{c}{ Number captured by year } \\
\cline { 3 - 9 } Reservoir & Site & 2010 & 2011 & 2012 & 2013 & 2014 & 2015 & 2016 & TOTAL \\
\hline Lake Mead & EB & 601 & 3818 & 439 & 40 & 119 & 137 & 737 & 5891 \\
& LB & 145 & 449 & 274 & 505 & 538 & 104 & 367 & 2382 \\
& VR/MR & 16 & 21 & 4 & 191 & 215 & 98 & 63 & 608 \\
& CRI & 7 & 65 & 10 & 0 & 160 & 48 & 14 & 304 \\
Lake Powell & PCR & NS & NS & NS & NS & 881 & 1293 & NS & 1274 \\
& PSJ & NS & 1 & 0 & NS & NS & NS & NS & 1 \\
\hline
\end{tabular}

TABLE 2. Fish community composition from trammel net captures at Lake Mead (LM) from 2010 to 2016, the Colorado River inflow to Lake Powell (PCR) in 2014 and 2015, and the San Juan River inflow to Lake Powell (PSJ) in 2011 and 2012.

\begin{tabular}{|c|c|c|c|c|}
\hline Species & Scientific name & LM & PCR & PSJ \\
\hline Black Bullhead & Ameiurus melas & $0.96 \%$ & $0.51 \%$ & $1.71 \%$ \\
\hline Black Crappie & Pomoxis nigromaculatus & $0.36 \%$ & $0.40 \%$ & $1.55 \%$ \\
\hline Blue Tilapia & Oreochromis aureus & $0.26 \%$ & $0.00 \%$ & $0.00 \%$ \\
\hline Bluegill & Lepomis macrochirus & $2.51 \%$ & $6.37 \%$ & $13.90 \%$ \\
\hline Bluehead Sucker & Catostomus discobolus & $0.01 \%$ & $0.01 \%$ & $0.02 \%$ \\
\hline Bonytail & Gila elegans & $0.00 \%$ & $0.03 \%$ & $0.00 \%$ \\
\hline Channel Catfish & Ictalurus punctatus & $5.68 \%$ & $6.12 \%$ & $14.20 \%$ \\
\hline Colorado Pikeminnow & Ptychocheilus lucius & $0.00 \%$ & $0.01 \%$ & $0.09 \%$ \\
\hline Common Carp & Cyprinus carpio & $17.80 \%$ & $40.50 \%$ & $19.80 \%$ \\
\hline Flannelmouth Sucker & Catostomus latipinnis & $1.98 \%$ & $0.07 \%$ & $1.05 \%$ \\
\hline Gizzard Shad & Dorosoma cepedianum & $60.80 \%$ & $35.90 \%$ & $29.50 \%$ \\
\hline Green Sunfish & Lepomis cyanellus & $0.09 \%$ & $1.60 \%$ & $3.61 \%$ \\
\hline Hybrid Sucker & & $0.06 \%$ & $0.00 \%$ & $0.04 \%$ \\
\hline Largemouth Bass & Micropterus salmoides & $1.73 \%$ & $0.74 \%$ & $3.20 \%$ \\
\hline Rainbow Trout & Oncorhynchus mykiss & $0.06 \%$ & $0.00 \%$ & $0.00 \%$ \\
\hline Razorback Sucker & Xyrauchen texanus & $0.86 \%$ & $2.04 \%$ & $0.95 \%$ \\
\hline Sailfin Catfish & Pterygoplichthys sp. & $0.02 \%$ & $0.00 \%$ & $0.00 \%$ \\
\hline Smallmouth Bass & Micropterus dolomieu & $0.09 \%$ & $0.87 \%$ & $3.97 \%$ \\
\hline Striped Bass & Morone saxatilis & $4.63 \%$ & $1.48 \%$ & $2.92 \%$ \\
\hline Threadfin Shad & Dorosoma petenense & $1.53 \%$ & $0.82 \%$ & $0.60 \%$ \\
\hline Walleye & Sander vitreus & $0.01 \%$ & $1.87 \%$ & $0.51 \%$ \\
\hline Yellow Bullhead & Ameiurus natalis & $0.50 \%$ & $0.69 \%$ & $2.46 \%$ \\
\hline
\end{tabular}

Razorback Suckers were a small fraction of the catch (Lake Mead $<1 \%$, PCR $=2 \%$, PSJ $<1 \%$ ). Nonnative species such as Gizzard Shad, Common Carp, Bluegill (Lepomis macrochirus), Channel Catfish (Ictalurus punctatus), Striped Bass (Morone saxatilis), Smallmouth Bass (Micropterus dolomieu), and Largemouth Bass (Micropterus salmoides) were the most abundant species.

Trammel netting efforts yielded 551 Razorback Suckers from 2010 to 2016 across all sites within Lake Mead for a reservoir-wide mean catch per unit effort (fish/net-hour) of 0.024 (SE 0.002). This includes the capture of 18 wild juvenile Razorback Suckers, which composed $3.3 \%$ of the native fish catch dur- ing this time period. Juvenile Razorback Suckers ranged in size from 215 to $444 \mathrm{~mm}$ TL and were sexually immature at the time of capture. At the PCR, 427 Razorback Suckers were captured using trammel netting during 2014-2015 for a mean catch per unit effort of 0.067 (SE 0.006; Table 3). An additional 189 Razorback Suckers were captured at the PCR using electrofishing. At the PSJ, 108 Razorback Suckers were captured with trammel nets during 2011-2012 for a mean catch per unit effort of 0.017 (SE 0.003; Table 3). An additional 55 Razorback Suckers were captured at the PSJ using electrofishing.

In Lake Mead, $59 \%$ of the Razorback Suckers captured during 2010 and 2016 were 
TABLE 3. Razorback Sucker catch per unit effort from 2010 to 2016 at each sampling site in Lake Mead and Lake Powell. $\mathrm{EB}=$ Echo Bay, LB = Las Vegas Bay, VR/MR = Virgin River/Muddy River inflow area, CRI = Colorado River inflow area, PCR $=$ Lake Powell-Colorado River inflow area, PSJ = Lake Powell-San Juan inflow area.

\begin{tabular}{lccc}
\hline Reservoir & Site & $\begin{array}{c}\text { CPUE } \\
\text { (fish/net-hour) }\end{array}$ & $\begin{array}{c}\text { Standard } \\
\text { error }\end{array}$ \\
\hline Lake Mead & EB & 0.041 & 0.006 \\
& LB & 0.020 & 0.004 \\
& VR/MR & 0.092 & 0.011 \\
Lake Powell & CRI & 0.007 & 0.001 \\
& PCR & 0.067 & 0.006 \\
& PSJ & 0.017 & 0.003 \\
\hline
\end{tabular}

unmarked wild fish. Within the PCR (20142015), approximately $90 \%$ of captured Razorback Suckers were recaptured stocked individuals. However, within the PSJ (2011-2012), approximately $44 \%$ of the individuals captured were unmarked fish, while $56 \%$ were recaptured stocked individuals.

The TL of Razorback Suckers was significantly different among all 3 study areas (ANOVA: $F_{2,1284}=336.7, P<0.001$, Tukey HSD). Length distributions from fish captured at the PCR and PSJ indicate that fish from those locations are, on average, smaller than Razorback Suckers from Lake Mead. Razorback Suckers in Lake Mead had a mean length of $559 \mathrm{~mm}$ (SE 2.94), while Razorback Suckers from the PCR and PSJ had mean lengths of $479 \mathrm{~mm}$ (SE 1.63) and $499 \mathrm{~mm}$ (SE 3.13), respectively (Fig. 3A). Growth rate was not significantly different between study areas (ANOVA: $F_{2,117}=1.50, P=0.226$ ). Mean growth in Lake Mead, the PCR, and the PSJ was $15.9 \mathrm{~mm} /$ year (SE 1.16), $16.2 \mathrm{~mm} /$ year (SE 3.13), and $7.11 \mathrm{~mm} /$ year (SE 3.32), respectively. However, von Bertalanffy growth curves indicate that Razorback Suckers grow similarly in the Lake Powell sites, both in rate and maximum predicted size, while fish in Lake Mead appear to grow faster and to a larger overall size (Fig. 3B).

Mean body condition estimates using relative weights between the 3 study areas (Fig. 3C) were significantly different (ANOVA: $F_{2,1266}=48.3, P<0.001$, Tukey-Kramer HSD). The PSJ ( $\left.W_{r}=89\right)$ fish showed poorer condition than the PCR $\left(W_{r}=101\right)$ fish, and the Lake Mead $\left(W_{r}=94\right)$ fish were of an intermediate condition. Razorback Suckers with condition estimates greater than 150 were mostly large spawning females.
Age Determination

We updated the recruitment graph from Albrecht et al. (2010) using ages determined from 544 Lake Mead Razorback Suckers captured through 2016. Razorback Suckers aged from this time period were recruited from year classes spanning 1966 to 2011 (Fig. 4). The direct captures of age- 2 to age- 4 Razorback Suckers from Lake Mead inflow areas provide additional evidence of ongoing recruitment. Prior to 2000, the majority of aged fish were spawned during high reservoir elevations while the reservoir was relatively stable around full pool. However, recent data show that Lake Mead Razorback Sucker recruitment readily occurred beyond 2000, which coincided with a steady decline of reservoir elevations (Fig. 4). Approximately $78 \%$ of the 544 fish aged were spawned from 2000 to 2011. Age data also demonstrate that some level of recruitment is possible in Lake Mead regardless of reservoir elevation, as presumed natural recruitment has been documented near annually through 2011 (Fig. 4). Lack of juvenile fish captured within the last 4-5 years is thought to be indicative of fish being too small to be sampled with the gear used, rather than a lack of fish spawned during recent year classes.

From 2010 to 2016, 308 individual Lake Mead Razorback Suckers were aged. Age was determined for 79 Razorback Suckers from the PCR; these fish were assigned year classes as early as 2001. Age was determined for 82 Razorback Suckers from the PSJ, which were assigned to year classes as early as 1992. The mean ages of fish captured in Lakes Mead and Powell were 7.7 years in Lake Mead, 7.9 years in the PCR, and 9.6 years in the PSJ (at time of first capture) (Fig. 5). Razorback Suckers from the PSJ were significantly older than those in the other 2 study areas, while the fish from Lake Mead and the PCR did not significantly differ in age (ANOVA: $F_{2,468}=23.0, P<0.001$, Tukey-Kramer HSD).

\section{Discussion}

The inflow areas of Lake Mead and Lake Powell are examples of areas where an imperiled species can spawn, recruit to adulthood (Lake Mead), and persist. The ability of the Razorback Sucker to use habitats within 


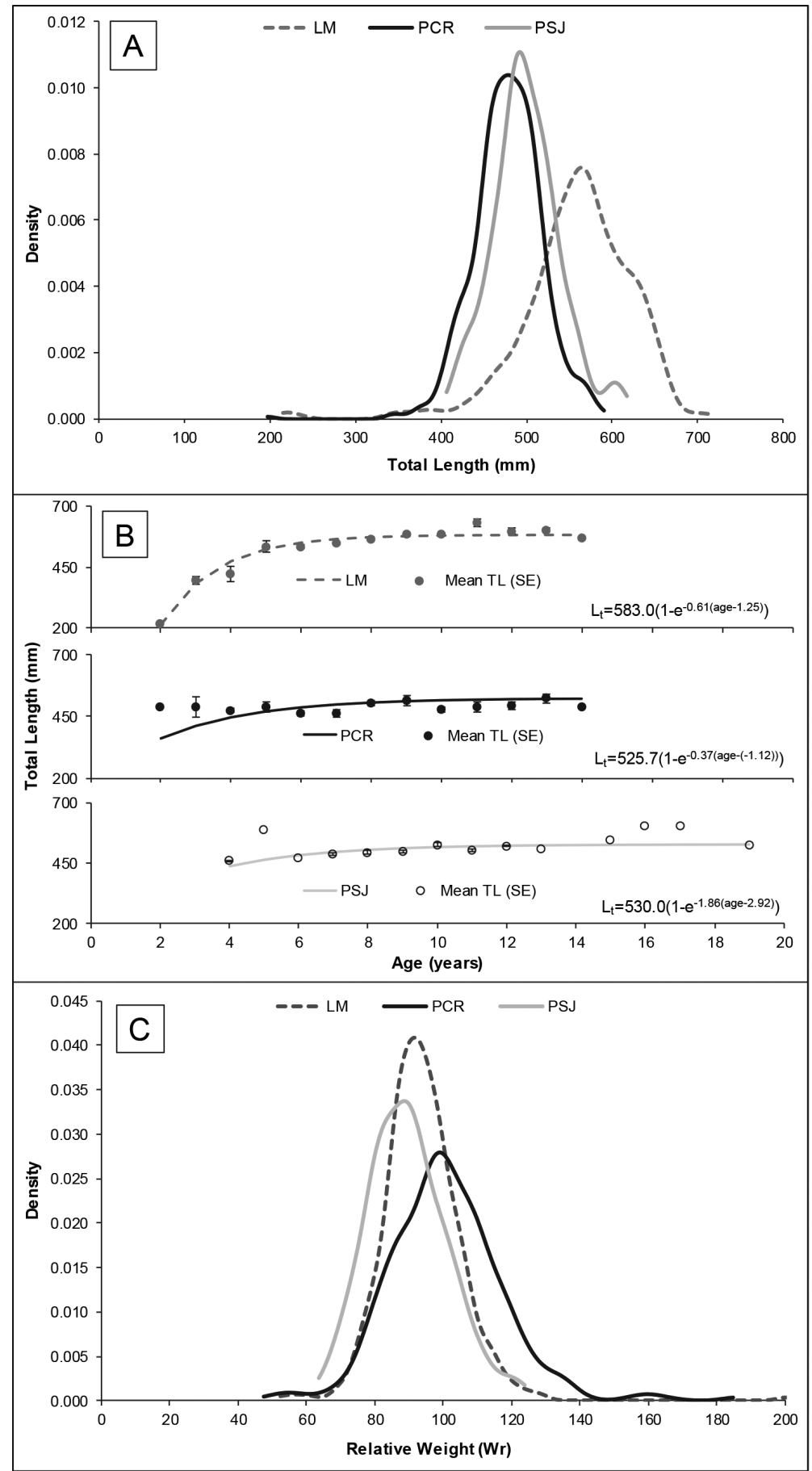

Fig. 3. (A) Total length of Razorback Suckers captured, graphed using a kernel density function where the shape of the curve depends on the density of localized data points in a given area. The area under each curve is standardized to equal a value of 1.0. (B) von Bertalanffy growth curve for the Razorback Sucker fitted to mean length-at-age $( \pm$ SE) in the 3 reservoir sites. (C) Condition factor (relative weight) of Razorback Suckers at the 3 reservoir sites using a kernel density function where the shape of the curve depends on the density of localized data points in a given area. The area under each curve is standardized to equal a value of 1.0. Site abbreviations: LM = Lake Mead (2010-2016), PCR = the Colorado River arm of Lake Powell (2014-2015), and PSJ = the San Juan River arm of Lake Powell (2011-2012). 


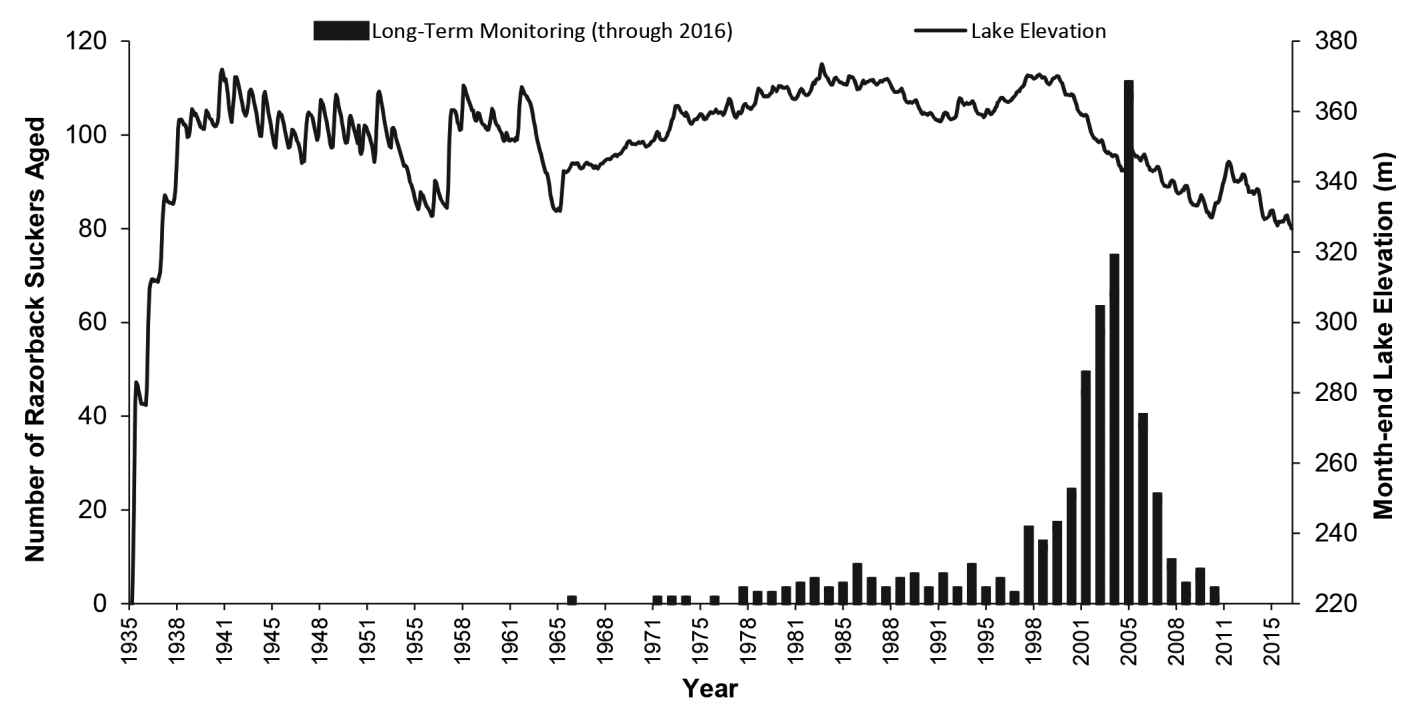

Fig. 4. Cumulative number of Lake Mead Razorback Suckers back-calculated to year spawned for aged individuals, with corresponding Lake Mead month-end lake elevations, January 1935-June 2016.

inflow areas demonstrates the plasticity of this species. Prior to dam and levee construction throughout the Colorado River basin, backwaters, flooded wetlands, slackwaters, and offchannel habitats with dynamic, turbid, warm, diverse, and complex habitats were commonly available (Mueller and Marsh 2002, Mueller 2006, Bestgen et al. 2011, Marsh et al. 2015). Through this comparison of Razorback Sucker habitat use in Lakes Mead and Powell, we suggest that reservoir inflow areas likely function similarly to historic habitats and may be important to future conservation of this endangered species.

In Lake Mead, sonic/radio-tagged Razorback Suckers aggregated around inflow areas during both spawning and nonspawning months. Additionally, in Lake Mead, sonictagged juvenile Razorback Suckers moved toward inflow areas (especially areas with heavy cover, such as inundated vegetation and turbid water) shortly after being released into open-water habitats (Shattuck and Albrecht 2014). Increased cover in the form of turbidity, a common feature at many inflows, including the inflows of Lakes Mead and Powell, may provide protection from predation and could allow for greater survival of small fish (Wydoski and Wick 1998, Mueller 2006, Albrecht et al. 2010, 2014, Ward et al. 2016). Albrecht et al. (2010) reported that inflow areas of Lake Mead (Las Vegas Bay and Echo
Bay) had significantly higher amounts of vegetative cover and turbidity compared with 2 similar bays in Lake Mohave. While active sonic telemetry still needs to be conducted to establish habitat use patterns within Lake Powell, the close association of Razorback Suckers year-round with inflow areas in Lake Mead suggests the importance of these habitats to this species.

Our findings from tracking the Razorback Sucker's use of inflows appear consistent with findings from reservoir-wide larval sampling that was previously conducted in Lake Mead. For example, systematic shoreline sampling of Lake Mead resulted in finding concentrations of larval Razorback Sucker near inflow areas (Holden et al. 2000a, 2000b, 2001). These early efforts, coupled with ongoing sampling, depict a long-term pattern of multiple life stages aggregating near inflow areas of Lakes Mead and Powell. In both Lakes Mead and Powell, reproduction occurred annually during our study period, as evidenced by larval Razorback Sucker captures (Francis et al. 2013, Mohn et al. 2016, Kegerries et al. 2017). While larval captures were low at the PSJ, this may not indicate lack of spawning success; rather, we suggest that additional and consistent larval sampling is needed at the PSJ. The use of larval light traps, similar to methods used in the PCR, may help field crews be more effective in sampling for larval Razorback Suckers. 


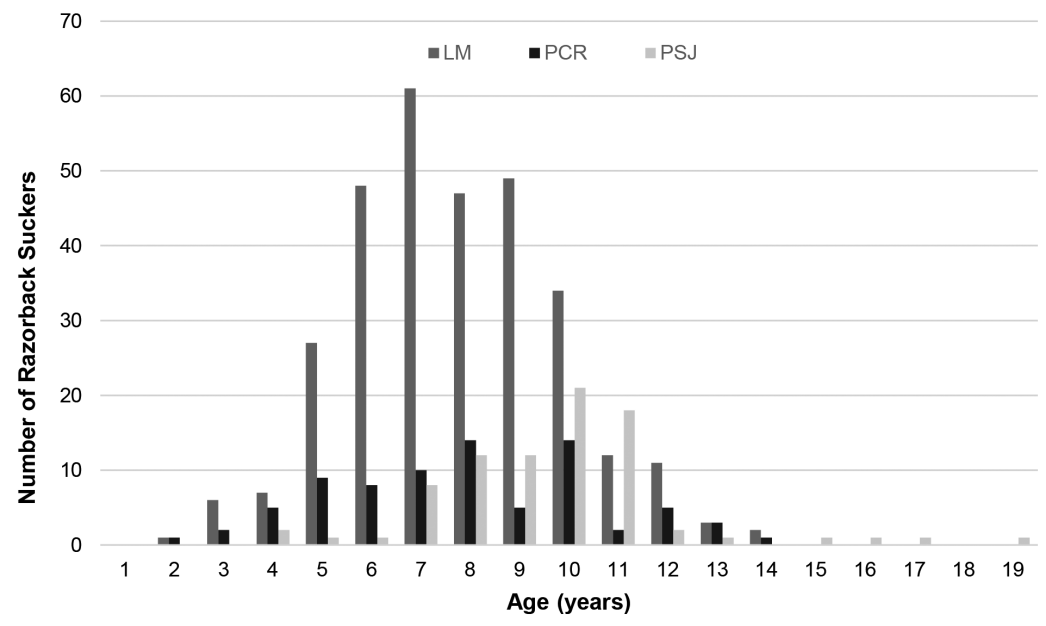

Fig. 5. Age and number of Razorback Suckers captured in Lake Mead (LM, 2010-2016), the Colorado River arm of Lake Powell (PCR, 2014-2015), and the San Juan River arm of Lake Powell (PSJ, 2011-2012).

Spawning that occurs at inflow areas and/or upstream of inflows to Lakes Mead and Powell could supply larvae to these reservoirs via larval drift (Albrecht et al. 2010, 2014, Bestgen et al. 2012, Farrington et al. 2015, Kegerries et al. 2017). Thus, it may be important to protect riverine and inflow populations of Razorback Sucker while further exploring population dynamics and interactions.

Growth rates between Lake Mead and Lake Powell were not significantly different. Condition estimates for Razorback Sucker in both systems suggest that these fish are healthy, but Lake Mead Razorback Suckers tend to be longer and grow faster than Lake Powell Razorback Suckers. Regardless, growth rates observed in this study are higher than those observed in other systems (Minckley 1983, Tyus 1987), suggesting that Lakes Mead and Powell provide suitable environments for growth of these fish.

Although juvenile Razorback Suckers have historically been rare in collections (Gutermuth et al. 1994, Modde 1996), researchers have captured juvenile Razorback Suckers and documented wild-origin Razorback Sucker recruitment almost annually in Lake Mead since the 1970s (Albrecht et al. 2010). Also, Razorback Sucker captures at the PSJ yielded high percentages of untagged fish (over $40 \%$ ). These rates are higher than those recently found in the San Juan River (reported as approximately 8\%-10\% from 2004 to 2012; Durst 2013). At the PCR, untagged fish ratios (also approximately 10\%) may be more similar to expected tag losses as observed within the upper Colorado River and its major tributaries (STReaMS 2017). In the Colorado River proper, approximately $9 \%(n=708)$ of Razorback Suckers encountered did not have PIT tags; similar metrics for the Gunnison River, Green River, and White River are 6\% $(n=$ $22), 9 \%(n=1061)$, and $8 \%(n=15)$, respectively (STReaMS 2017). Whether this information represents the potential for natural recruitment in the PSJ should be a focus of future investigations.

Research to quantify habitat use by all life stages and increased sampling efforts in the flowing river portions of inflow areas may provide additional insights into the importance of inflows for Razorback Sucker survival and recruitment. For example, reservoir-wide telemetry and larval sampling in Lake Powell, as well as investigations using methods described herein at other inflows of these 2 reservoirs (e.g., the Dirty Devil inflow in Lake Powell and Bonelli Bay in Lake Mead) could better inform our understanding of Razorback Sucker use of these reservoirs. The Lake Mead and Lake Powell inflow areas appear to link important riverine and lacustrine habitats, and we should consider these inflow areas more fully in regard to ongoing recovery efforts for Razorback Sucker. Finally, we advocate that managers actively consider these inflow locations and their apparent ability to provide habitat for this imperiled species. 


\section{ACKNOWLEDGMENTS}

This project was funded by the U.S. Bureau of Reclamation, Upper Colorado Region, Salt Lake City, Utah, and the Lower Colorado River Multi-Species Conservation Program, Boulder City, Nevada. We thank all collaborators on these projects, including the U.S. Fish and Wildlife Service, U.S. National Park Service, Arizona Game and Fish Department, Nevada Department of Wildlife, Utah Division of Wildlife Resources, Southern Nevada Water Authority, and the Navajo Nation. We express gratitude to Darrel Snyder, Howard Brandenberg, and Steven Platania for assistance and efforts with identification and verification of larval specimens and to Glen Busch for his assistance with mapping needs. Finally, we thank Dr. Paul Holden, Sandra Livingston Turner, and all anonymous peer reviewers who commented on and helped improve earlier versions of this work. Reference to trade names does not imply endorsement by the U.S. Government.

\section{Literature Cited}

Albrecht, B., P.B. Holden, R. Kegerries, and M.E. GOLDEN. 2010. Razorback sucker recruitment in Lake Mead, Nevada-Arizona, why here? Lake and Reservoir Management 26(4):336-344.

Albrecht, B., R. Kegerries, J.M. Barkstedt, W.H. Brandenburg, A.L. Barkalow, S.P. Platania, M. McKinstry, B. Healy, J. Stolberg, and Z. ShatTUCK. 2014. Razorback sucker Xyrauchen texanus research and monitoring in the Colorado River inflow area of Lake Mead and the lower Grand Canyon, Arizona and Nevada. Final Report. U.S. Bureau of Reclamation, Upper Colorado Region, Salt Lake City, UT.

Albrecht, B., T. Sanderson, and P. Holden. 2008. Razorback Sucker studies on Lake Mead, Nevada and Arizona 1996-2007 comprehensive report. U.S. Bureau of Reclamation - Lower Colorado Region, Boulder City, NV, and Southern Nevada Water Authority - Surface Water Resources Department, Las Vegas, NV. PR-1093-2.

Bestgen, K.R., G.B. Haines, and A.A. Hill. 2011. Synthesis of flood plain wetland information: timing of Razorback Sucker reproduction in the Green River, Utah, related to stream flow, water temperature, and flood plain wetland availability. Final Report. Larval Fish Laboratory Contribution 163, Upper Colorado River Endangered Fish Recovery Program, Denver, CO.

Bestgen, K.R., K.A. Zelasko, and G.C. White. 2012. Monitoring reproduction, recruitment, and population status of Razorback Suckers in the upper Colorado River Basin. Final Report. Larval Fish Laboratory Contribution 170, Upper Colorado River Endangered Fish Recovery Program, Denver, CO.
BIDGOOD, B.F. 1980. Field surgical procedure for implantation of radio tags in fish. Fisheries Research Report No. 20, Alberta Fish and Wildlife Division, Department of Energy and Natural Resources. 10 pp.

Bunt, C.M., S.J. Cooke, C. Katopodis, and R.S. McKinLEY. 1999. Movement and summer habitat of Brown Trout (Salmo trutta) below a pulsed discharge hydroelectric generating station. Regulated Rivers: Research and Management 15:395-403.

Burke, T. 1995. Rearing wild Razorback Sucker larvae in lake-side backwaters, Lake Mohave, Arizona/Nevada [abstract]. Proceedings of the Desert Fishes Council 26:35.

Dalrymple, G.B., and W.K. Hamblin. 1998. K-Ar of Pleistocene lava dams in the Grand Canyon in Arizona. Proceedings of the National Academy of Sciences 95:9744-9749.

Didenko, A.V., S.A. Bonar, And W.J. Matter. 2004. Standard weight $\left(W_{\mathrm{s}}\right)$ equations for four rare desert fishes. North American Journal of Fisheries Management 24(2):697-703.

Dowling, T.E., M.J. Saltzgiver, D. Adams, and P.C. Marsh. 2012. Genetic variability in a recruiting population of endangered Razorback Suckers from Lake Mead, Arizona-Nevada. Transactions of the American Fisheries Society 141(4):990-999.

Durst, S.L. 2013. 2012 Integrated PIT tag database summary of Colorado Pikeminnow and Razorback Sucker in the San Juan River. Final Report. U.S. Bureau of Reclamation, Salt Lake City, UT.

Durst, S.L., AND T.A. Francis. 2016. Razorback Sucker transbasin movement through Lake Powell, Utah. Southwestern Naturalist 61:60-63.

Fabens, A.J. 1965. Properties and fitting of the von Bertalanffy growth curve. Growth 29(3):265-289.

Farrington, M.A., R.K. Dudley, J.L. Kennedy, S.P. Platania, and G.C. White. 2015. Colorado Pikeminnow and Razorback Sucker larval fish survey in the San Juan River during 2014. Final Report. U.S. Bureau of Reclamation, Salt Lake City, UT, and the San Juan River Basin Recovery and Implementation Program, Albuquerque, NM.

Francis, T.A., D.W. Ryden, B.J. Schleicher, and D.S. Elverud. 2013. San Juan Arm of Lake Powell Razorback Sucker (Xyrauchen texanus) Survey: 2011; Interim Progress Report (Final). U.S. Bureau of Reclamation, Salt Lake City, UT.

Gutermuth, F.B., L.D. Lentsch, AND K.R. Bestgen. 1994. Collection of age-0 Razorback Suckers (Xyrauchen texanus) in the lower Green River, Utah. Southwestern Naturalist 39:389-391.

GuY, C.S., AND M.L. BRown, EDITORs. 2007. Analysis and interpretation of freshwater fisheries data. American Fisheries Society, Bethesda, MD.

HinEs, B.A. 2011. Relative importance of environmental variables for spawning cues and tributary use by an adfluvial lake sucker. Master's thesis. Utah State University, Logan, UT.

Holden, P.B., P.D. Abate, and J.B. Ruppert. 1997. Razorback Sucker studies on Lake Mead, Nevada. 1996-1997 Annual Report, PR-578-1. Department of Resources, Southern Nevada Water Authority, Las Vegas, NV.

Holden, P.B., P.D. Abate, And J.B. Ruppert. 2000a. Razorback Sucker studies on Lake Mead, Nevada. 19981999 Annual Report, PR-578-3. Department of Resources, Southern Nevada Water Authority, Las Vegas. 
Holden, P.B., P.D. Abate, and J.B. Ruppert. 2000b. Razorback sucker studies on Lake Mead, Nevada. 1999-2000 Annual Report, PR-578-4. Prepared for the Department of Resources, Southern Nevada Water Authority, by BIO-WEST, Inc., Logan, UT.

Holden, P.B., P.D. Abate, and T.L. Welker. 2001. Razorback Sucker studies on Lake Mead, Nevada. 2000-2001 Annual Report, PR-578-5. Department of Resources, Southern Nevada Water Authority, Las Vegas, NV.

Holden, P.B., and C.B. Stalnaker. 1975. Distribution of fishes in the Dolores and Yampa River systems of the upper Colorado Basin. Southwestern Naturalist 19:403-412.

Johnson, J.E., AND R.T. Hines. 1999. Effect of suspended sediment on vulnerability of young Razorback Sucker to predation. Transactions of the American Fisheries Society 128:648-655.

Joseph, T.W., J.A. Sinning, R.J. Behnke, And P.B. HoLDEN. 1977. An evaluation of the status, life history, and habitat requirements of endangered and threatened fishes of the upper Colorado River system. U.S. Fish and Wildlife Service, Office of Biological Services, Fort Collins, CO.

Kaeding, L.R., B.D. Burdick, P.A. Schrader, and C.W. MCADA. 1990. Temporal and spatial relations between the spawning of Humpback Chub and Roundtail Chub in the Upper Colorado River. Transactions of the American Fisheries Society 119:135-144.

Kaemingk, M.A., B.D.S. Graeb, C.W. Hoagstrom, and D.W. WiLLIS. 2007. Patterns of fish diversity in a mainstem Missouri River and reservoir and associated delta in South Dakota and Nebraska, USA. River Research and Applications 23:786-791.

Karp, C.A., AND G. MuelLer. 2002. Razorback Sucker movements and habitat use in the San Juan River inflow, Lake Powell, Utah, 1995-1997. Western North American Naturalist 62:106-111.

Kegerries, R.B., B.C. Albrecht, E.I. Gilbert, W.H Brandenburg, A.L. Barkalow, M.C. McKinstry, H.E. Mohn, B.D. Healy, J.R. Stolberg, E.C. Omana SMith, ET AL. 2017. Occurrence and reproduction by Razorback Sucker Xyrauchen texanus in the Grand Canyon, Arizona. Southwestern Naturalist 62 : 227-232.

Kegerries, R., B. Albrecht, R. Rogers, E. Gilbert, W.H. Brandenburg, A.L. Barkalow, S.P. Platania, M. McKinstry, B. Healy, J. Stolberg, et al. 2016. Razorback Sucker Xyrauchen texanus research and monitoring in the Colorado River inflow area of Lake Mead and the lower Grand Canyon, Arizona and Nevada. Final Report. U.S. Bureau of Reclamation, Upper Colorado Region, Salt Lake City, UT.

Killgore, K.J. 1991. Techniques used in fishery evaluation studies. Pages 71-85 in L. Sanders, editor, Techniques for evaluating aquatic habitats in rivers, streams, and reservoirs. Paper W-91-2, Waterways Experimental Station, U.S. Army Corps of Engineers, Vicksburg, MS.

Lumley, T., P. Diehr, S. Emerson, and L. Chen. 2002. The importance of the normality assumption in large public health data sets. Annual Review of Public Health 23:151-169.

Marsh, P.C., T.E. Dowling, B.R. Kesner, T.F. Turner, AND W.L. MinckLEY. 2015. Conservation to stem imminent extinction: the fight to save Razorback Sucker Xyrauchen texanus in Lake Mohave and its implications for species recovery. Copeia 2015: $141-156$.

Marsh, P.C., C.A. Pacey, and B.R. Kesner. 2003. Decline of Razorback Sucker in Lake Mohave, Colorado River, Arizona and Nevada. Transactions of the American Fisheries Society 132:1251-1256.

Marty, G.D., and R.C. Summerfelt. 1990. Wound healing in Channel Catfish by epithelialization and contraction of granulation tissue. Transactions of the American Fisheries Society 115:577-589.

MCCALL, T. 1980. Fishery investigation of Lake Mead, Arizona-Nevada, from Separation Rapids to Boulder Canyon, 1978-79. Water and Power Resources Service, Boulder City, NV. Final Report. 197 pp.

McCarthy, M.S., and W.L. Minckley. 1987. Age estimation for Razorback Sucker (Pisces: Catostomidae) from Lake Mohave, Arizona and Nevada. Journal of Arizona-Nevada Academy of Science 21:87-97.

Miller, R.R. 1958. Origins and affinities of the freshwater fish fauna of western North America. Pages 187-222 in C.L. Hubbs, editor, Zoogeography, Publication 51. American Association for the Advancement of Science, Washington, DC.

Minckley, W.L. 1973. Fishes of Arizona. Arizona Game and Fish Department, Phoenix, AZ.

MinckLeY, W.L. 1983. Status of the Razorback Sucker, Xyrauchen texanus (Abbott), in the lower Colorado River basin. Southwestern Naturalist 28:165-187.

MincKley, W.L., and J.E. Deacon, EDitors. 1991. Battle against extinction: native fish management in the American West. University of Arizona Press, Tucson.

MincKley, W.L., D.A. HendRickson, and C.E. Bond. 1986. Geography of western North American freshwater fishes: description and relationships to intracontinental tectonism. Pages 519-614 in C.H. Hocutt and E.O. Wiley, editors, The zoogeography of North American freshwater fishes. John Wiley \& Sons, New York, NY. 866 pp.

Minckley, W.L., AND P.C. Marsh. 2009. Inland fishes of the greater Southwest. University of Arizona Press, Tucson, AZ.

Minckley, W.L., P.C. Marsh, J.E. Brooks, J.E. Johnson, AND B.L. JENSEN. 1991. Management toward recovery of Razorback Sucker. Pages 303-357 in W.L. Minckley and J.E. Deacon, editors, Battle against extinction: native fish management in the American West. University of Arizona Press, Tucson, AZ.

Minckley, W.L., P.C. Marsh, J.E. Deacon, T.E. Dowling, P.W. Hedrick, W.J. Matthews, and G. Mueller. 2003. A conservation plan for native fishes of the Lower Colorado River. BioScience 53:219-234.

Modde, T. 1996. Juvenile Razorback Sucker (Xyrauchen texanus) in a managed wetland adjacent to the Green River. Great Basin Naturalist 56:375-376.

Mohn, H.E, B. Albrecht, R. Rogers, and R. Kegerries. 2016. Razorback Sucker Xyrauchen texanus studies on Lake Mead, Nevada and Arizona. 2015-2016 Annual Report. U.S. Bureau of Reclamation, Lower Colorado River Multi-Species Conservation Program, Boulder City, NV.

MueLLER, G.A. 2006. Ecology of Bonytail and Razorback Sucker and the role of off-channel habitats in their recovery. Scientific Investigations Report 2006-5056, U.S. Department of the Interior, U.S. Geological Survey, Reston, VA.

Mueller, G., M. Horn, J. Kahl Jr., T. Burke, and P. Marsh. 1993. Use of larval light traps to capture 
Razorback Sucker (Xyrauchen texanus) in Lake Mohave, Arizona-Nevada. Southwestern Naturalist 38:399-402.

Mueller, G.A., AND P.C. Marsh. 2002. Lost, a desert river and its native fishes: a historical perspective of the Lower Colorado River. Information and Technology Report 2002-0010, U.S. Geological Survey, Fort Collins Science Center, Fort Collins, CO.

Pallant, J. 2007. SPSS survival manual, a step by step guide to data analysis using SPSS for Windows. 3rd edition. McGraw Hill, Sydney, Australia.

Shattuck, Z., and B. Albrecht. 2014. Sonic telemetry and habitat use of juvenile Razorback Suckers in Lake Mead. Final Annual Report prepared for Bureau of Reclamation: Lower Colorado River MultiSpecies Conservation Program. Boulder City, NV.

Snyder, D.E., And R.T. Muth. 2004. Catostomid fish larvae and early juveniles of the Upper Colorado River basin-morphological descriptions, comparisons, and computer-interactive key. Technical Publication No. 42, Colorado Division of Wildlife, Colorado State University Larval Fish Laboratory, Fort Collins, CO.

Snyder, D.E., S.C. Seal, J.A. Charles, and C.L. Bjork. 2016. Cyprinid fish larvae and early juveniles of the Upper Colorado River basin: morphological descriptions, comparisons, and computer-interactive key. Technical Publication No. 47, Upper Colorado River Endangered Fish Recovery Program, Colorado State University Larval Fish Laboratory, Fort Collins, CO.

[STReaMS] Species Tagging, Research and MonitorING System. 2017. Online database for data from the Upper Colorado and San Juan River Endangered Fish Recovery Programs. Colorado Natural Heritage Program, Colorado State University, Warner College of Natural Resources; [accessed 9 September 2017]. https://streamsystem.org

Tyus, H.M. 1987. Distribution, reproduction, and habitat use of the Razorback Sucker in the Green River,
Utah, 1979-1986. Transactions of the American Fisheries Society 116:111-116.

[USFWS] United States Fish and Wildlife Service. 1991. Endangered and threatened wildlife and plants; the Razorback Sucker (Xyrauchen texanus) determined to be an endangered species; Final rule. Federal Register 56 (23 October 1991):54957-54967.

[USFWS] United States Fish and Wildlife Service. 2009. Final Gunnison River Basin Programmatic Biological Opinion. U.S. Fish and Wildlife Service Ecological Services, Colorado Field Office, Denver, CO.

VALDEZ, R.A., AND B.C. NiLson. 1982. Radiotelemetry as a means of assessing movement and habitat selection of humpback chub. Transactions of the Bonneville Chapter of the American Fisheries Society 182: 29-39.

Ward, D.L., R. Morton-Starner, and B. Vaage. 2016. Effects of turbidity on predation vulnerability of juvenile Humpback Chub to Rainbow Trout and Brown Trout. Journal of Fish and Wildlife Management 7:205-212.

Wick, E.J., C.W. McAdA, and R.V. BulkLey. 1982. Life history and prospects for recovery of the Razorback Sucker. Pages 120-126 in W.H. Miller, H.M. Tyus, and C.A. Carlson, editors, Fishes of the Upper Colorado River system: present and future. American Fisheries Society, Western Division, Bethesda, MD.

WYDOSKI, R.S., AND E.J. WICK. 1998. Ecological value of floodplain habitats to Razorback Sucker in the upper Colorado River Basin. Final Report. U.S. Fish and Wildlife Service, Recovery Implementation Program for the Recovery of Endangered Fishes in the Upper Colorado River Basin, Denver, CO.

Received 9 February 2017

Accepted 23 October 2017 Published online 2 February 2018 